\title{
Development and Adsorption Characterization of Metal Affinity- Immobilized Magnetic Liposome
}

\author{
Yuan Lu, ${ }^{1}$ Dankui Liao, ${ }^{2}$ Xuezhen Feng, ${ }^{1}$ Hualin Meng, ${ }^{1}$ Yuting Lu, ${ }^{1}$ Qiqiu Wei, \\ Siliang Duan, ${ }^{1}$ and Shanguang $\mathrm{Wu}\left(\mathbb{1}^{1}\right.$ \\ ${ }^{1}$ Medical College, Guangxi University of Science and Technology, Liuzhou 545006, China \\ ${ }^{2}$ Guangxi Key Laboratory of Petrochemical Resource Processing and Process Intensification Technology, School of Chemistry and \\ Chemical Engineering, Guangxi University, Nanning 530004, China
}

Correspondence should be addressed to Shanguang Wu; wsg_gxust1974@163.com

Received 12 September 2019; Revised 24 December 2019; Accepted 23 January 2020; Published 11 February 2020

Academic Editor: Hiromasa Nishikiori

Copyright ( 2020 Yuan Lu et al. This is an open access article distributed under the Creative Commons Attribution License, which permits unrestricted use, distribution, and reproduction in any medium, provided the original work is properly cited.

\begin{abstract}
A metal affinity-immobilized magnetic liposome (MA-IML) was prepared in this research, which was with lipid and $\mathrm{Ni}^{2+}$ content of $143.25 \mu \mathrm{g} / \mathrm{mg}$ and $32 \mu \mathrm{mol} / \mathrm{mg}$, respectively. The antihypertensive peptides Ile-Pro-Pro (IPP) and Val-Pro-Pro (VPP) could be adsorbed onto MA-IML under specific conditions, and the adsorption kinetics was explored. The pseudo-second-order kinetics $\left(R^{2}\right.$ value $\left.>0.98\right)$ was more suitable to describe the adsorption process of IPP and VPP than the intraparticle diffusion model and pseudo-first-order kinetic model. The results indicated that MA-IML could be used as an adsorbent for screening antihypertensive peptides from natural products.
\end{abstract}

\section{Introduction}

Hypertension is one of the main life-threatening diseases in the world. In the presence of angiotensin-converting enzyme (ACE), angiotensin I (Ang I) can be converted to angiotensin II (Ang II). Ang II leads to vasoconstriction and elevation of blood pressure and degrades bradykinin which has antihypertensive effect. Angiotensin-converting enzyme inhibitors (ACEI) can lower blood pressure by inhibiting the ACE activity and reducing the production of Ang II. At present, synthetic ACE inhibitors are widely used as antihypertensive drugs in clinical practice. But they have serious side effects such as cough and angioneurotic edema $[1,2]$. Therefore, recent research has focused on the development of ACE inhibitors that come from natural products and have low side effects. Over 200 ACE inhibitory peptides, called antihypertensive peptides, have been found from different kinds of food protein hydrolysates [3]. Among them, the antihypertensive peptides Ile-Pro-Pro (IPP) and Val-Pro-Pro (VPP) were proved in a single-blind, placebo-controlled study [4] and used as food additive in drinks. Antihypertensive effect of valyl-tyrosine derived from sardine muscle hydrolyzate was confirmed on mild hypertensive subjects [5]. Much of research has showed antihypertensive peptides with different structures can be obtained by enzymolysis and fermentation. The majority of ACEI are relatively short sequences containing 2 to 12 amino acids. Structure activity studies indicated that ACEI containing hydrophobic amino acid residues at each C-terminal position may have high ACE inhibitory activity [3]. There is a positive correlation between the hydrophobicity of the ultimate C-terminal amino acid and the ACE inhibitory activity of ACEI [6].

It is difficult to isolate and enrich ACEI, because protein hydrolysates are mixtures of many components. At present, most of ACEI are usually purified using several chromatographic steps including size exclusion, ionic exchange, and RP-HPLC chromatography. Those methods are timeconsuming and inefficient. Affinity chromatography is a powerful separation technique for proteins and peptides, and some of them have been reported in purification of ACEI in recent years [7-10]. In 2014, a new chromatographic technique, the metal affinity-immobilized liposome chromatography (MA-ILC), was developed by Nagami et al. [11], which may have the characteristics of both the 
immobilized metal affinity chromatography (IMAC) and the immobilized liposome chromatography (ILC). IMAC is a separation technique that uses the affinity differences between peptides and metal ions [12-14], and immobilized liposomes are known to interact with proteins or peptides via hydrophobic interaction. So the MA-ILC has the metal affinity and the hydrophobic adsorption, which may be a powerful separation technique for ACEI, because of hydrophobic properties of ACEI. However, the pretreatment and operation of MA-ILC is complex.

By combining magnetic separation technique and MA-ILC, we develop a new magnetic adsorbent, metal affinity-immobilized magnetic liposome (MA-IML), in this study. It may have the characteristics of MA-ILC and may be easy to operate and facilitate the batch recovery of the adsorbent with the aid of a magnet simply. To obtain MAIML, the magnetic liposomes containing N-hexadecyl iminodiacetic acid (HIDA) will be firstly prepared and then coupled with metal ions $\left(\mathrm{Ni}^{2+}\right)$. Furthermore, the adsorption kinetics of MA-IML with antihypertensive peptides IPP and VPP will be studied.

\section{Materials and Methods}

2.1. Reagents and Chemicals. IPP and VPP were purchased from GL Biochem (Shanghai) Ltd. Hexadecylamine and ethyl bromoacetate were purchased from Sinopharm Chemical Reagent Co., Ltd. Lipid was purchased from Shanghai Tywei Pharmaceutical Co., Ltd. Methanol and acetonitrile were of HPLC grade and purchased from Thermo Fisher (NJ, USA). The other chemicals were of analytical reagent grade.

2.2. Synthesis Process of HIDA. HIDA was synthesized according to reference with a slight modification [15]. In brief, hexadecylamine and ethyl bromoacetate were added into a $250 \mathrm{~mL}$ flask, in which the mass ratio of hexadecylamine and ethyl bromoacetate was 2-3. Under magnetic stirring, $10.36 \mathrm{~g}$ of potassium carbonate, $2.49 \mathrm{~g}$ of potassium iodide, and $50 \mathrm{~mL}$ of dimethylformamide were added into the mixture and refluxed at $90^{\circ} \mathrm{C}$ for $12 \mathrm{~h}$. After that, the reaction solution was cooled to room temperature, diluted by $120 \mathrm{~mL}$ deionized water, and extracted by ethyl acetate. The organic phase was concentrated in vacuo, and $200 \mathrm{~mL}$ of $0.5 \mathrm{~mol} / \mathrm{L} \mathrm{NaOH}$ solutions was added to dissolve the residue. The homogeneous solution was refluxed at $90^{\circ} \mathrm{C}$ for $2 \mathrm{~h}$, cooled to room temperature, and acidified by $6 \mathrm{~mol} / \mathrm{L} \mathrm{HCl}$ to $\mathrm{pH} 1$. After filtration, the crude HIDA products were obtained and then recrystallized with ethanol.

The identification of products was carried out by MS and ${ }^{1} \mathrm{H}-\mathrm{NMR}$, using a 106B Ultra-High-Resolution Liquid Mass Spectrometry System (Thermo Fisher Scientific) and a Bruker $300 \mathrm{MHz}$ NMR spectrometer, respectively.

\subsection{Preparation and Characterization of $M A-I M L$}

2.3.1. Preparation of $M A-I M L$. Magnetic nanoparticles (MN) were prepared according to the following protocol. Briefly, $\mathrm{FeCl}_{3} \cdot 6 \mathrm{H}_{2} \mathrm{O}$ and $\mathrm{FeCl}_{2} \cdot 4 \mathrm{H}_{2} \mathrm{O}$ were dissolved in $50 \mathrm{~mL}$ water at the concentration of $0.077 \mathrm{~mol} / \mathrm{L}$ ions firstly (the molar ratio of $\mathrm{FeCl}_{3} \cdot 6 \mathrm{H}_{2} \mathrm{O}$ to $\mathrm{FeCl}_{2} \cdot 4 \mathrm{H}_{2} \mathrm{O}$ was 1.88 ). The chemical precipitation was achieved by adding $5.5 \mathrm{~mL}$ of $25 \%$ $\mathrm{NH}_{3} \cdot \mathrm{H}_{2} \mathrm{O}$ into the above solution at $30^{\circ} \mathrm{C}$ under nitrogen atmosphere and continuous stirring $\left(800 \mathrm{r} \cdot \mathrm{min}^{-1}\right)$ for $30 \mathrm{~min}$; then, the reaction temperature was raised to $80^{\circ} \mathrm{C}$. After incubation for $30 \mathrm{~min}$ at $80^{\circ} \mathrm{C}$, the $\mathrm{MN}$ were precipitated with permanent magnet at room temperature and rinsed with distilled water for six times to remove unreacted chemicals.

Magnetic liposomes (ML) containing HIDA were prepared as follows. (I) The required amount of lipid (typically around $20 \mathrm{mg} / \mathrm{mL}$ ) and HIDA was (the mass ratio of lipid/HIDA was 2) dissolved in $100 \mathrm{~mL}$ of ethanol and then transferred to a round bottom flask. The organic phase was subsequently removed using a rotary evaporator at $40^{\circ} \mathrm{C}$, and then, a thin film was deposited on the inside wall of the round bottom flask. (II) The $\mathrm{MN}$ were dispersed in $50 \mathrm{~mL}$ of water and then added into the lipid film with ultrasound for $10 \mathrm{~min}$. The $\mathrm{ML}$ were precipitated with permanent magnet and rinsed with distilled water to remove the liposomes without magnetism.

Finally, MA-IML was prepared by mixing the ML and $20 \mathrm{~mL}$ nickel sulfate solution $(0.05 \mathrm{~mol} / \mathrm{mL})$ and incubation for $60 \mathrm{~min}$ at $37^{\circ} \mathrm{C}$. The excess of $\mathrm{Ni}^{2+}$ was removed by washing the adsorbents with distilled water. According to the previous report [16], $\mathrm{Ni}^{2+}$ content of MA-IML was determined by a UV-1900 UV-Vis spectrophotometer (Shimadzu, China) at $662 \mathrm{~nm}$, using a standard curve $C=$ $0.0872 A+0.0009$.

2.3.2. Determination of Lipid Content of $M A-I M L$. Lipid content of MA-IML was measured according to Reference [17]. Firstly, $4 \mathrm{~mL}$ trichloromethane was added into $0.01 \mathrm{~g}$ MA-IML, in order to destroy the structure of magnetic liposomes. Then, $2 \mathrm{~mL}$ ammonium ferrothiocyanate was mixed well with it. The mixture was shaken well and centrifuged at a rate of $3000 \mathrm{r} / \mathrm{min}$ using a TDL-80$2 \mathrm{~B}$ centrifuge, and the supernatant liquid was discarded. After filtration, lipid content of MA-IML was determined by a UV-1900 UV-Vis spectrophotometer (Shimadzu, China) at $451 \mathrm{~nm}$, using a standard curve $C=0.1013 A-$ 0.0047 .

2.3.3. Size Determination and Transmission Electron Microscopy (TEM). Size and distribution of MA-IML, which was diluted with distilled water, were determined via the Nano S90 particle size analyzer (Malvern Instruments Ltd.), using a dynamic light scattering method. Transmission electron microscopy analyses were carried out using JEOL JSM2100F from Prime Japan's Hitachi. The MA-IML fluid was dropped onto a copper mesh grid and visualized by TEM after negative staining with $1 \%$ phosphotungstic acid solution $(\mathrm{pH}=7.0)$.

2.4. Determination of Antihypertensive Peptides by HPLC. The determination of VPP and IPP was analyzed by HPLC with ZORBAX SB-C18 $(4.6 \mathrm{~mm} \times 150 \mathrm{~mm}, 5 \mu \mathrm{m}$; Agilent). The peptide was eluted by a linear gradient 
hrz \#2 RT: 0.01 AV: 1 NL: 1.90E7

T: FTMS + p ESI Full ms [200.00-500.00]

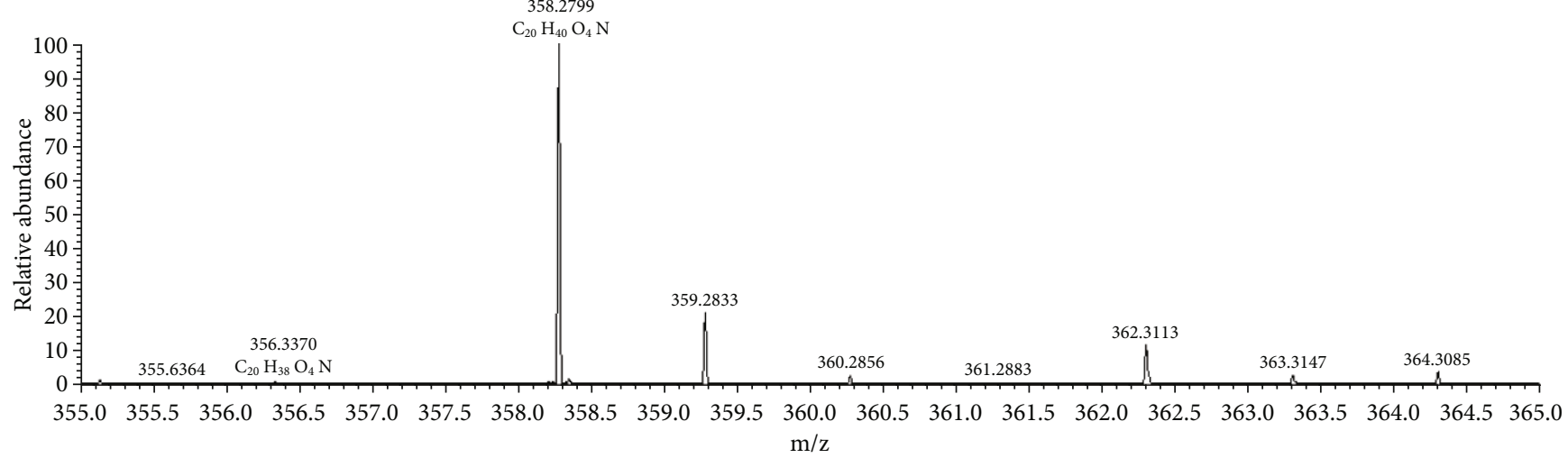

Figure 1: MS spectrum of the synthetic HIDA.

method from solvent A (water containing 0.1\% TFA) to $100 \%$ of solvent B (acetonitrile containing $0.1 \%$ TFA) over a period of $30 \mathrm{~min}$ at a flow rate of $1.0 \mathrm{~mL} / \mathrm{min}$ and was detected at $220 \mathrm{~nm}$. Two linear regression equations for IPP and VPP were, respectively, established as follows: $y=767.99 x-11289\left(R^{2}=0.9948\right)$ and $y=684.55$ $x-602.66\left(R^{2}=0.9864\right)$, where $y$ is the peak area and $x$ is the amount of IPP or VPP.

2.5. Adsorption Experiment. In a typical experiment, $300 \mathrm{mg}$ of MA-IML particles was mixed with IPP or VPP solutions in $2 \mathrm{~mL}$ centrifuge tubes.

The effects of operating parameters such as various initial concentrations of IPP or VPP and time on the adsorption process were studied. The initial $\mathrm{pH}$ of the test solution was modified by adding the $0.1 \mathrm{~mol} / \mathrm{L}$ borate buffer solution (BBS, pH value of 8.5).

The centrifuge tubes were placed in a rotary shaker and incubated at $37^{\circ} \mathrm{C}$ with gentle stirring $(120 \mathrm{r} / \mathrm{min})$. The solutions were immediately filtered through a $0.22 \mu \mathrm{m}$ membrane filter at different incubating time, and concentration of IPP or VPP in the filtrate was measured. The equilibrium adsorption capacity $(q, \mathrm{mg} / \mathrm{g})$ was calculated as follows [18]:

$$
q=\frac{\left(C_{0}-C_{1}\right) V}{m}
$$

where $C_{0}\left(\mathrm{mg} \cdot \mathrm{mL}^{-1}\right)$ is the initial concentration of IPP or VPP solution, $C_{1}\left(\mathrm{mg} \cdot \mathrm{mL}^{-1}\right)$ is the concentration of IPP or VPP solution at equilibrium, $V(\mathrm{~mL})$ is the volume of solution, and $m(\mathrm{~g})$ is the mass of MA-IML particles.

Furthermore, several adsorption models were applied to describe the adsorption mechanism between MA-IML and IPP or VPP, such as the intraparticle diffusion model, pseudo-first-order model, and pseudo-second-order model. The equation corresponding to the intraparticle diffusion model (Weber-Morris) is the following [19]:

$$
q_{t}=k_{\mathrm{p}} t^{0.5}
$$

The pseudo-first-order kinetic model is given as follows [20]:

$$
\ln \left(q_{\mathrm{e}}-q_{t}\right)=\ln q_{\mathrm{e}}-k_{1} t
$$

The pseudo-second-order kinetic model defined the adsorption mechanism. It can be articulated by the subsequent equation [21]:

$$
\frac{t}{q_{t}}=\frac{1}{\left(k_{2} q_{\mathrm{e}}^{2}\right)}+\frac{t}{q_{\mathrm{e}}}
$$

where $q_{t}$ and $q_{\mathrm{e}}(\mathrm{mg} / \mathrm{g})$ are the amounts of IPP or VPP adsorbed at time $t(\mathrm{~min})$ and at equilibrium, respectively. $k_{\mathrm{p}}\left(\mathrm{mg} \cdot \mathrm{g}^{-1} \cdot \mathrm{min}^{-1 / 2}\right)$ is the intraparticle diffusion rate constant, $k_{1}\left(\mathrm{~min}^{-1}\right)$ is the rate constant of the pseudo-first-order model, and $k_{2}\left(\mathrm{~g} \cdot \mathrm{mg}^{-1} \cdot \mathrm{min}^{-1}\right)$ is the rate constant of the pseudosecond-order model.

\section{Results and Discussion}

3.1. Characterization of HIDA. HIDA has the structure that allows it to be easily incorporated into liposome membranes due to the acyl chain attached to the ligand, iminodiacetic acid (IDA). The metal ion on the ML surface was to be immobilized through the coordination with HIDA [14]. However, HIDA is not currently on sale and was made in our laboratory. HIDA was successfully synthesized, and structure of HIDA was identified by MS and ${ }^{1} \mathrm{H}-\mathrm{NMR}$. The MS spectrum of the synthetic HIDA is shown in Figure 1. The calculated $m / z$ for $\mathrm{C}_{20} \mathrm{H}_{40} \mathrm{O}_{4} \mathrm{~N}$ $[\mathrm{M}+]$ is 358.2799 , which is consistent with the $\mathrm{m} / z$ for HIDA. Figure 2 shows the results of ${ }^{1} \mathrm{H}-\mathrm{NMR}(300 \mathrm{MHz}$, $\left.\mathrm{CDCl}_{3}\right): \delta 3.40(s, 4 \mathrm{H}), 2.61(t, 2 \mathrm{H}), 1.23(m, 28 \mathrm{H})$, and $0.85(t, 3 \mathrm{H})$. The purity of the synthetic HIDA was above $99 \%$.

3.2. Characterization of $M A-I M L$. The lipid content and $\mathrm{Ni}^{2+}$ content of MA-IML were $143.25 \mu \mathrm{g} / \mathrm{mg}$ and $32 \mu \mathrm{mol} / \mathrm{mg}$, respectively. The effects of the mass ratio of lipid/HIDA on the lipid and $\mathrm{Ni}^{2+}$ content in MA-IML are shown in Tables 1 and 2 . The results in Table 1 


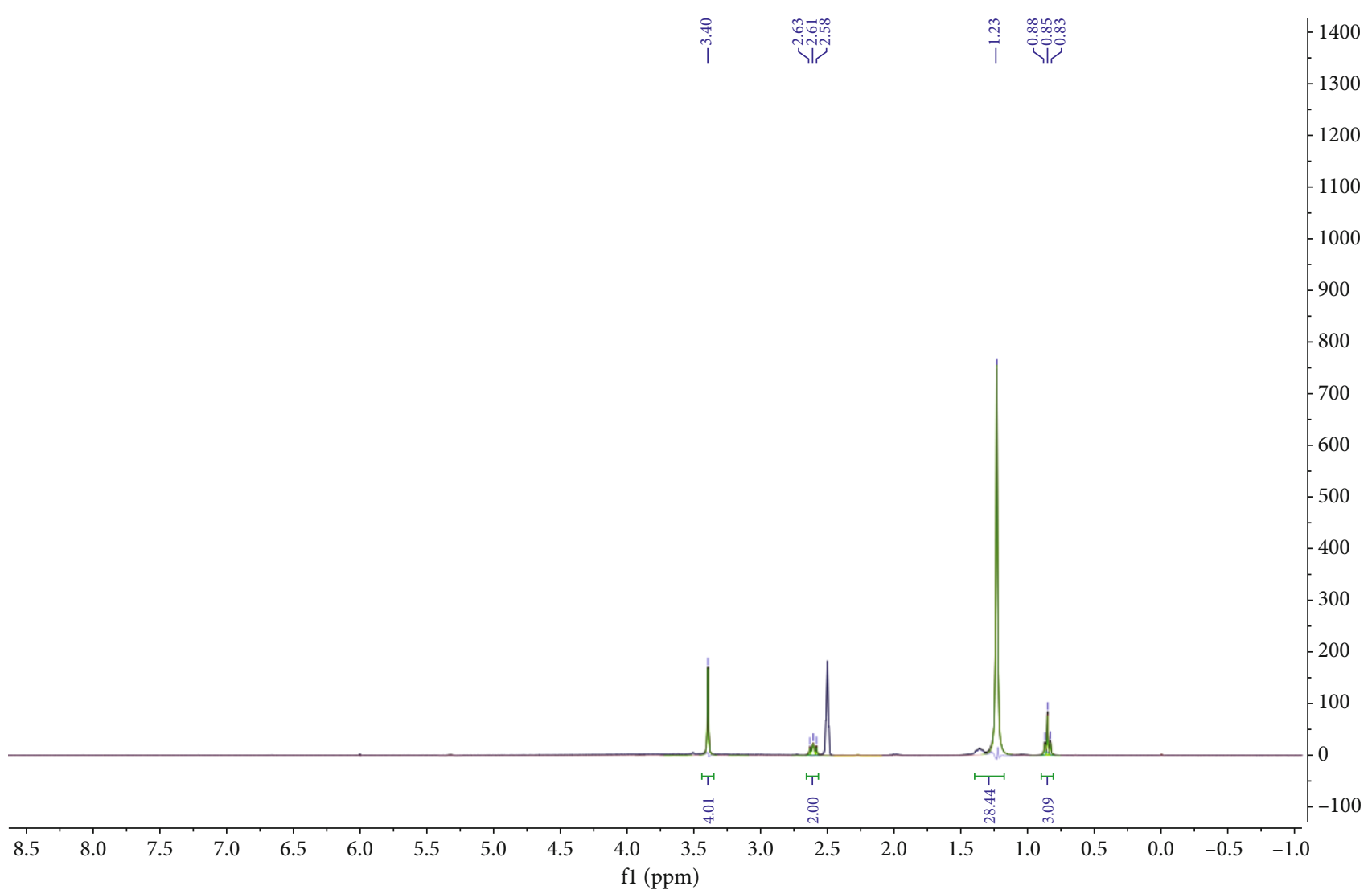

Figure 2: ${ }^{1} \mathrm{H}-\mathrm{NMR}$ spectrum of the synthetic HIDA.

TABLE 1: Lipid content of MA-IML according to the mass ratio of lipid/HIDA.

\begin{tabular}{lc}
\hline Lipid/HIDA & Lipid content $(\mu \mathrm{g} / \mathrm{mg})$ \\
\hline 1 & 104.30 \\
2 & 143.25 \\
3 & 157.42 \\
4 & 164.92 \\
5 & 173.70 \\
\hline
\end{tabular}

TABLE $2: \mathrm{Ni}^{2+}$ content of MA-IML according to the mass ratio of lipid/HIDA.

\begin{tabular}{lc}
\hline Lipid/HIDA & $\mathrm{Ni}^{2+}$ content $(\mu \mathrm{mol} / \mathrm{mg})$ \\
\hline 1 & 35 \\
2 & 32 \\
3 & 11 \\
4 & 5 \\
5 & 4 \\
\hline
\end{tabular}

showed that the lipid content increased as the mass ratio of lipid/HIDA varied from 1 to 5 , while the $\mathrm{Ni}^{2+}$ content decreased as shown in Table 2. The adsorption capability to $\mathrm{Ni}^{2+}$ would be probably affected if the amount of HIDA was little, so the mass ratio of lipid/HIDA was not more

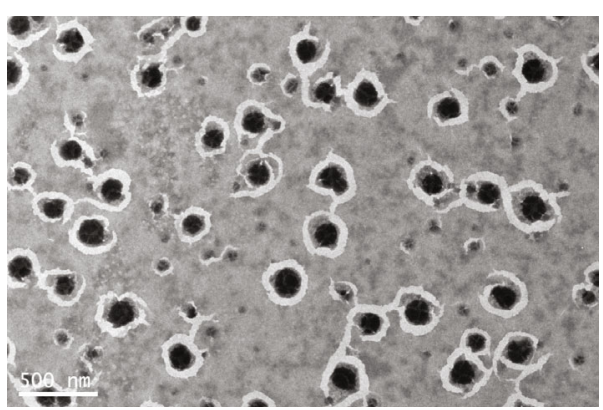

FIgURE 3: Transmission electron microscope image of MA-IML $(\times 7000)$.

than 5. When the mass ratio of lipid/HIDA was 1 , the $\mathrm{Ni}^{2+}$ content was the maximum, but the lipid content was too low. Therefore, the mass ratio of lipid/HIDA of 2 was chosen when preparing MA-IML.

After negative staining with phosphotungstic acid solution, the lipid layer of MA-IML particle was observed by TEM (the light circle in Figure 3), and the dark sphere in Figure 3 was the inner core consisting of $\mathrm{Fe}_{3} \mathrm{O}_{4}$. These particles were near-spherical and had good dispersity. The particle size distribution of MA-IML is shown in Figure 4. The results showed that MA-IML had a particle size distribution of $100-500 \mathrm{~nm}$ and an average particle size of about $300 \mathrm{~nm}$. 


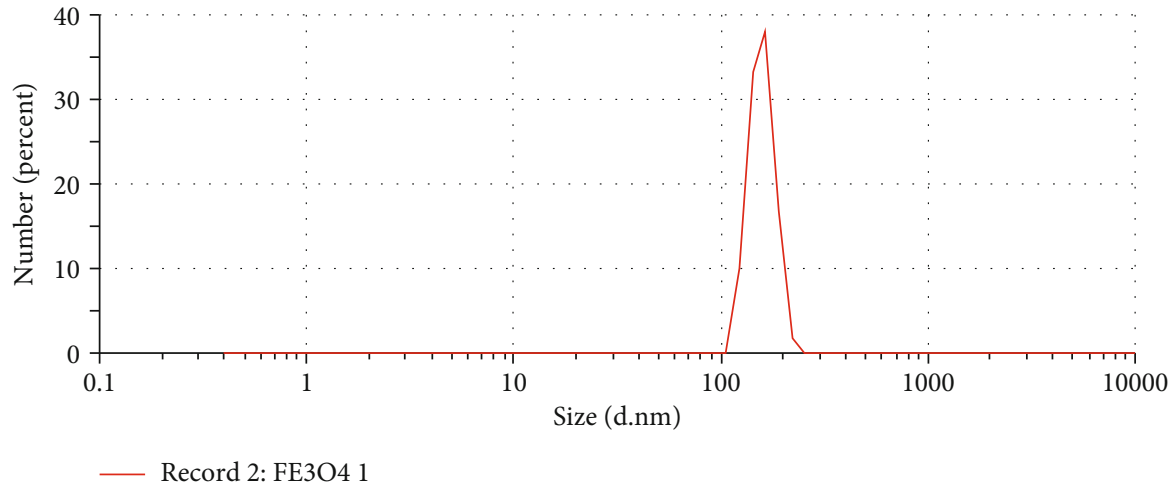

Figure 4: Particle size distribution of MA-IML.

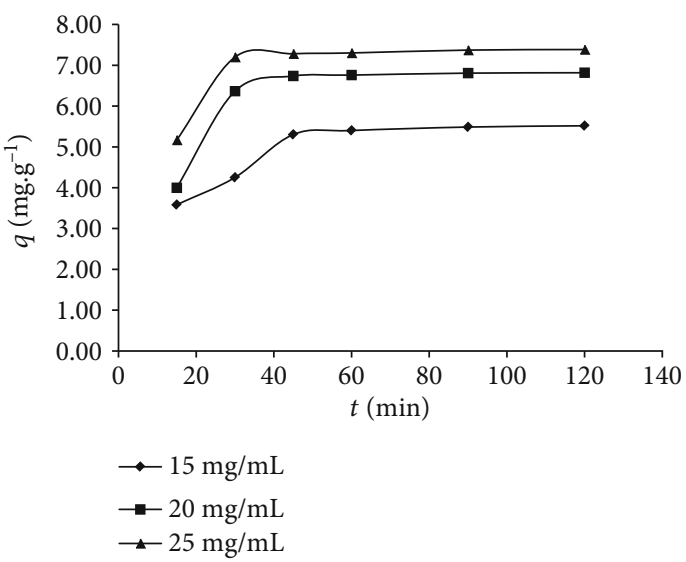

FIGURE 5: Adsorption kinetic curves of IPP onto MA-IML.

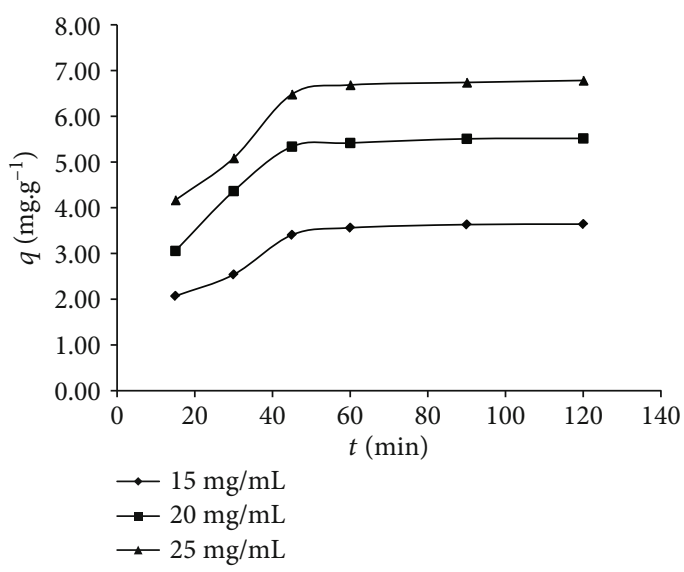

Figure 6: Adsorption kinetic curves of VPP onto MA-IML.

3.3. Adsorption Kinetic Study. Adsorption kinetics was usually evaluated to determine the contact time, which is required to reach the maximum adsorption capacity of an adsorbent with the equilibrium stage. Figures 5 and 6 show the influences of contact time on the adsorption of IPP and VPP, respectively. The curves showed that the amount of IPP and VPP adsorbed was gradually increased

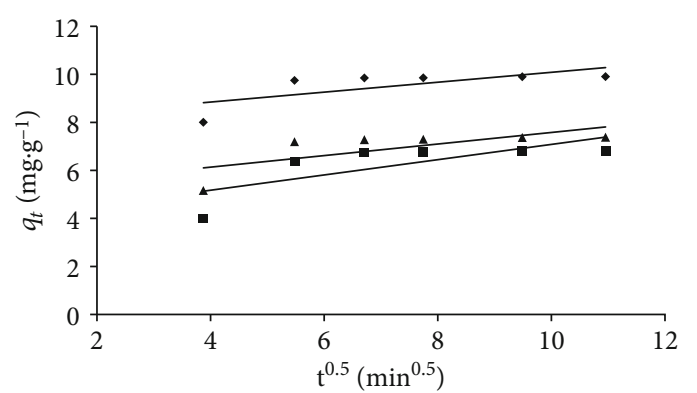

- $15 \mathrm{mg} / \mathrm{mL}$

- $20 \mathrm{mg} / \mathrm{mL}$

ง $25 \mathrm{mg} / \mathrm{mL}$

FIgURE 7: Intraparticle diffusion kinetics of IPP adsorption onto MA-IML.

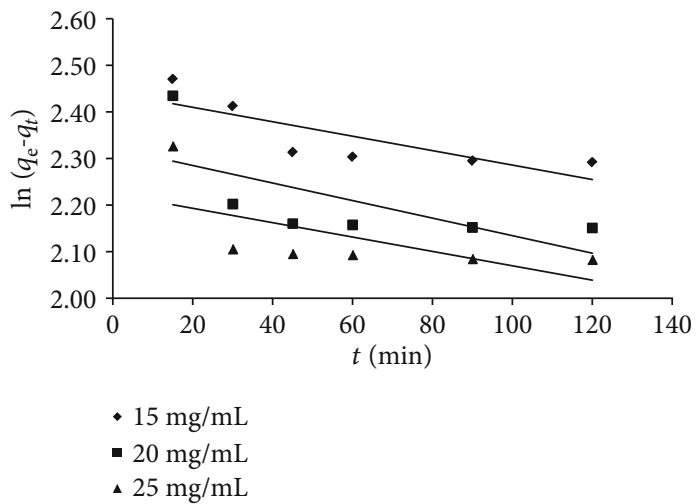

FIgURe 8: Pseudo-first-order kinetics of IPP adsorption onto MAIML.

in the first $30 \mathrm{~min}$ and the equilibrium adsorption capacity reached maximum at about $45 \mathrm{~min}$. At this time, the adsorption rate was approximately equal to the desorption rate.

Kinetic data were treated with the intraparticle diffusion model, pseudo-first-order model, and pseudosecond-order model, respectively. The fitting kinetic parameters of IPP or VPP absorbed onto MA-IML are shown in Figures 7-12 and Tables 3 and 4. By comparing 


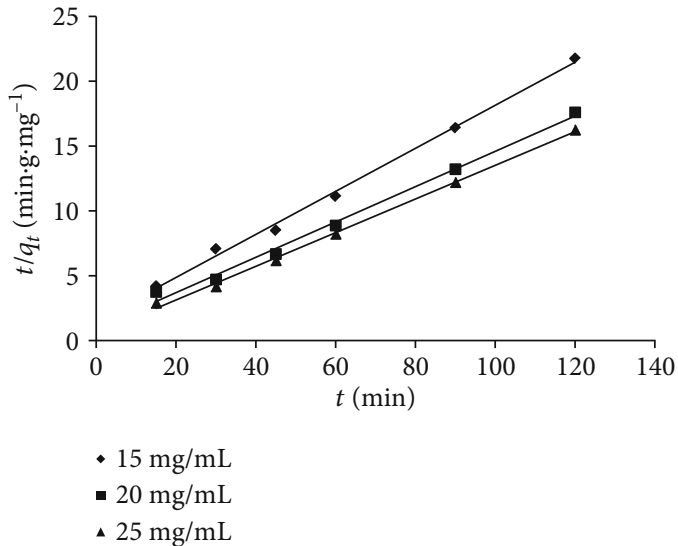

FIgURE 9: Pseudo-second-order kinetics of IPP adsorption onto MA-IML.

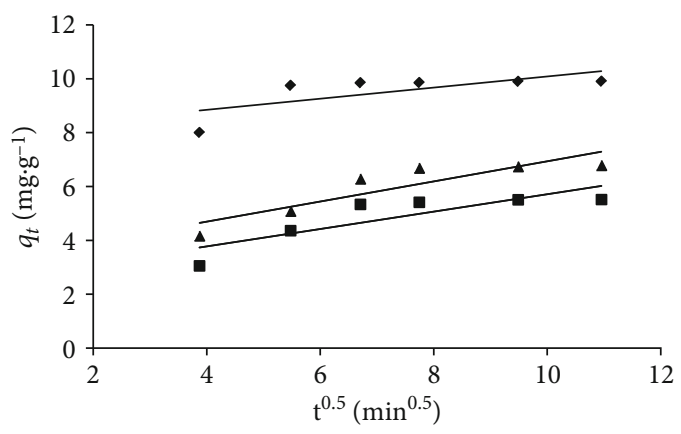

- $15 \mathrm{mg} / \mathrm{mL}$

- $20 \mathrm{mg} / \mathrm{mL}$

$\Delta 25 \mathrm{mg} / \mathrm{mL}$

Figure 10: Intraparticle diffusion kinetics of VPP adsorption onto MA-IML.

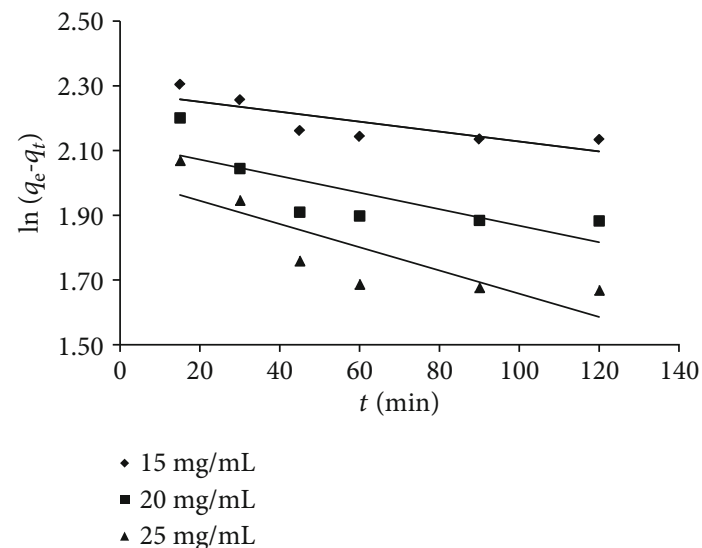

FIGURE 11: Pseudo-first-order kinetics of VPP adsorption onto MAIML.

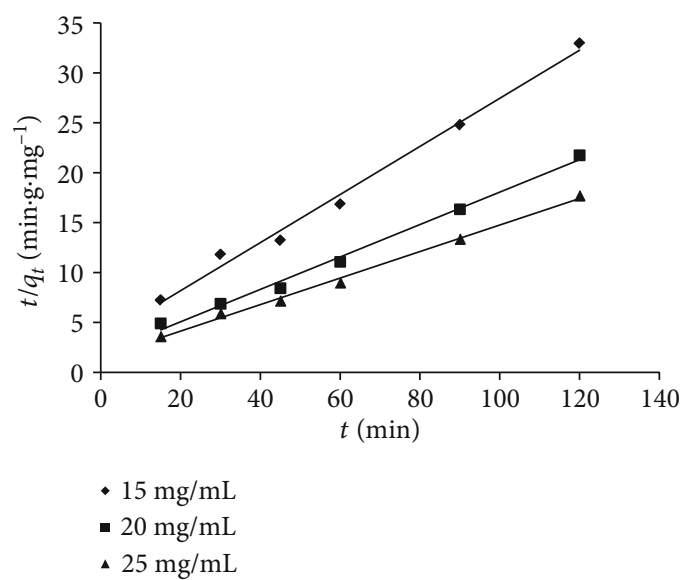

FIgURE 12: Pseudo-second-order kinetics of VPP adsorption onto MA-IML.

the $R^{2}$ values of different models, it was found that the pseudo-second-order kinetics $\left(R^{2}\right.$ value $\left.>0.98\right)$ was more suitable to describe the adsorption process of IPP and VPP than the intraparticle diffusion model and pseudofirst-order model. Similar results were observed when using the solutions with the different initial concentrations of 15,20 , and $25 \mathrm{mg} \cdot \mathrm{mL}^{-1}$.

It was the first trial that we used the prepared MAIML to adsorb antihypertensive peptides and investigate the adsorption kinetics. But the nonselective adsorption has not been discussed in this research. More conventional $\mathrm{Ni}^{2+}$ substrates would be tested to confirm the practical application of MA-IML. The adsorption mechanism of MA-IML is similar to MA-ILC. The main difference is that we made magnetic liposomes instead of liposome chromatography in order to simplify the operations. Magnetic properties can help recycle the adsorbents with the aid of a magnet. The adsorption advantages of combining the metal affinity and the hydrophobic interaction of liposomes have been compared with IMAC and ILC [11]. In the further research, we would investigate the adsorption behaviors of more peptides and the adsorption specificity of MA-IML.

\section{Conclusions}

MA-IML was prepared in this research. The lipid content and $\mathrm{Ni}^{2+}$ content of MA-IML were $143.25 \mu \mathrm{g} / \mathrm{mg}$ and $32 \mu \mathrm{mol} / \mathrm{mg}$, respectively. The MA-IML had a particle size distribution of 100-500 $\mathrm{nm}$ and an average particle size of about $300 \mathrm{~nm}$. These particles were near-spherical and had good dispersity.

The antihypertensive peptides IPP and VPP could be adsorbed onto MA-IML under specific conditions, and the adsorption kinetics was explored. Under the initial concentrations of 15,20 , and $25 \mathrm{mg} \cdot \mathrm{mL}^{-1}$, the pseudo-secondorder kinetics $\left(R^{2}\right.$ value $\left.>0.98\right)$ was more suitable to describe the adsorption process of IPP and VPP than the intraparticle 
TABLE 3: Adsorption kinetic constants of IPP onto MA-IML.

\begin{tabular}{lcccrr}
\hline $\begin{array}{l}\text { Initial concentration } \\
\text { of IPP }\left(\mathrm{mg} \cdot \mathrm{mL}^{-1}\right)\end{array}$ & \multicolumn{2}{c}{ Intraparticle infusion model } & \multicolumn{2}{c}{ Pseudo-first-order model } & \multicolumn{2}{c}{ Pseudo-second-order model } \\
& $k_{\mathrm{p}}\left(\mathrm{mg} \cdot \mathrm{g}^{-1} \cdot \mathrm{min}^{-1 / 2}\right)$ & $R^{2}$ & $k_{1}\left(\mathrm{~min}^{-1}\right)$ & $R^{2}$ & $k_{2}\left(\mathrm{~g} \cdot \mathrm{mg}^{-1} \cdot \mathrm{min}^{-1}\right)$ \\
\hline 15 & 0.206 & 0.501 & 0.001 & 0.652 & 0.166 \\
20 & 0.318 & 0.550 & 0.001 & 0.434 & 0.136 \\
25 & 0.240 & 0.509 & 0.001 & 0.394 & 0.993 \\
\hline
\end{tabular}

TABLE 4: Adsorption kinetic constants of VPP onto MA-IML.

\begin{tabular}{lcccrr}
\hline \multirow{2}{*}{$\begin{array}{l}\text { Initial concentration } \\
\text { of VPP }\left(\mathrm{mg} \cdot \mathrm{mL}^{-1}\right)\end{array}$} & \multicolumn{2}{c}{ Intraparticle infusion model } & \multicolumn{2}{c}{ Pseudo-first-order model } & \multicolumn{2}{c}{ Pseudo-second-order model } \\
& $k_{\mathrm{p}}\left(\mathrm{mg} \cdot \mathrm{g}^{-1} \cdot \mathrm{min}^{-1 / 2}\right)$ & $R^{2}$ & $k_{1}\left(\mathrm{~min}^{-1}\right)$ & $R^{2}$ & $k_{2}\left(\mathrm{~g} \cdot \mathrm{mg}^{-1} \cdot \mathrm{min}^{-1}\right)$ \\
\hline 15 & 0.228 & 0.782 & 0.001 & 0.674 & 0.240 \\
20 & 0.322 & 0.716 & 0.002 & 0.603 & 0.162 \\
25 & 0.373 & 0.797 & 0.003 & 0.700 & 0.991 \\
\hline
\end{tabular}

diffusion model and pseudo-first-order kinetic model. These results indicated that MA-IML could be used as an adsorbent for screening antihypertensive peptides that came from natural products.

\section{Data Availability}

The data used to support the findings of this study are available from the corresponding author upon request.

\section{Conflicts of Interest}

The authors declare that they have no conflicts of interest.

\section{Acknowledgments}

This work is supported by the National Natural Science Foundation of China (21766003), Guangxi Natural Science Foundation (2016GXNSFAA380055, 2017GXNSFDA198052, and 2018GXNSFAA294117), and Innovation and Entrepreneurship Training Program for College Students (201810594249).

\section{References}

[1] Z. H. Israili and W. D. Hall, "Cough and angioneurotic edema associated with angiotensin-converting enzyme inhibitor therapy: a review of the literature and pathophysiology," Annals of Internal Medicine, vol. 117, no. 3, pp. 234-242, 1992.

[2] T. F. T. Antonios and G. A. MacGregor, "Angiotensin converting enzyme inhibitors in hypertension: potential problems," Journal of Hypertension, vol. 13, Supplement 3, pp. S11-S16, 1995.

[3] B. Hernandez-Ledesma, M. del Mar Contreras, and I. Recio, "Antihypertensive peptides: production, bioavailability and incorporation into foods," Advances in Colloid and Interface Science, vol. 165, no. 1, pp. 23-35, 2011.

[4] S. Mizuno, K. Matsuura, T. Gotou et al., "Antihypertensive effect of casein hydrolysate in a placebo-controlled study in subjects with high-normal blood pressure and mild hypertension," British Journal of Nutrition, vol. 94, no. 1, pp. 84-91, 2005.
[5] T. Kawasaki, E. Seki, K. Osajima et al., "Antihypertensive effect of valyl-tyrosine, a short chain peptide derived from sardine muscle hydrolyzate, on mild hypertensive subjects," Journal of Human Hypertension, vol. 14, no. 8, pp. 519-523, 2000.

[6] J. Otte, S. M. Shalaby, M. Zakora, A. H. Pripp, and S. A. El-Shabrawy, "Angiotensin-converting enzyme inhibitory activity of milk protein hydrolysates: effect of substrate, enzyme and time of hydrolysis," International Dairy Journal, vol. 17, no. 5, pp. 488-503, 2007.

[7] C. Megías, J. Pedroche, M. . M. Yust et al., "Purification of angiotensin converting enzyme inhibitory peptides from sunflower protein hydrolysates by reverse-phase chromatography following affinity purification," LWT - Food Science and Technology, vol. 42, no. 1, pp. 228-232, 2009.

[8] S. Wu, X. Feng, X. Lan, Y. Xu, and D. Liao, "Purification and identification of Angiotensin-I Converting Enzyme (ACE) inhibitory peptide from lizard fish (Saurida elongata) hydrolysate," Journal of Functional Foods, vol. 13, pp. 295299, 2015.

[9] S. Wu, Y. Lu, Y. Tian, X. Feng, and S. Liu, "Preparation of immobilized metal affinity magnetic nanoparticles and its adsorption properties of protein," Food Industry, vol. 36, pp. 49-53, 2015.

[10] S. Wu, X. Feng, Y. Lu, Y. Lu, S. Liu, and Y. Tian, "Purification of angiotensin I-converting enzyme (ACE) inhibitory peptides from casein hydrolysate by IMAC-Ni ${ }^{2+}$," Amino Acids, vol. 49, no. 10, pp. 1787-1791, 2017.

[11] H. Nagami, H. Umakoshi, T. Kitaura, G. L. Thompson III, T. Shimanouchi, and R. Kuboi, "Development of metal affinity-immobilized liposome chromatography and its basic characteristics," Biochemical Engineering Journal, vol. 84, pp. 66-73, 2014.

[12] H. Block, B. Maertens, A. Spriestersbach et al., "Immobilizedmetal affinity chromatography (IMAC): a review," Methods in Enzymology, vol. 463, pp. 439-473, 2009.

[13] T. Abudiab and R. R. Beitle Jr., "Preparation of magnetic immobilized metal affinity separation media and its use in the isolation of proteins," Journal of Chromatography A, vol. 795, no. 2, pp. 211-217, 1998.

[14] Z. Liu, M. Li, Z. Li, F. Pu, J. Ren, and X. Qu, "Easy access to selective binding and recyclable separation of histidinetagged proteins using $\mathrm{Ni}^{2+}$-decorated superparamagnetic nanoparticles," Nano Research, vol. 5, no. 7, pp. 450-459, 2012. 
[15] K. Ng, D. W. Pack, D. Y. Sasaki, and F. H. Arnold, "Engineering protein-lipid interactions: targeting of histidine-tagged proteins to metal-chelating lipid monolayers," Langmuir, vol. 11, no. 10, pp. 4048-4055, 1995.

[16] J. Porath and B. Olin, "Immobilized metal affinity adsorption and immobilized metal affinity chromatography of biomaterials. Serum protein affinities for gel-immobilized iron and nickel ions," Biochemistry, vol. 22, no. 7, pp. 1621-1630, 1983.

[17] J. C. Stewart, "Colorimetric determination of phospholipids with ammonium ferrothiocyanate," Analytical Biochemistry, vol. 104, no. 1, pp. 10-14, 1980.

[18] O. Rahmanian, M. Dinari, and M. K. Abdolmaleki, "Carbon quantum dots/layered double hydroxide hybrid for fast and efficient decontamination of $\mathrm{Cd}(\mathrm{II})$ : the adsorption kinetics and isotherms," Applied Surface Science, vol. 428, pp. 272279, 2018.

[19] J. C. Morris and W. J. Weber, "Removal of biologicallyresistant pollutants from waste waters by adsorption," in Proceedings of the International Conference Held, pp. 231-266, London, UK, 1962.

[20] S. Largergren, "Zur theorie der sogenannten adsorption geloster stoffe Kungliga Svenska Vetenskapsakademiens," Handlingar, vol. 24, pp. 1-39, 1898.

[21] Y. S. Ho and G. Mckay, "Sorption of dye from aqueous solution by peat," Chemical Engineering Journal, vol. 70, no. 2, pp. 115-124, 1998. 